International Journal of Electrical Engineering and Technology (IJEET)

Volume 11, Issue 4, June 2020, pp. 175-180, Article ID: IJEET_11_04_020

Available online at https://iaeme.com/Home/issue/IJEET? Volume $=11 \&$ Issue $=4$

ISSN Print: 0976-6545 and ISSN Online: 0976-6553

DOI: https://doi.org/10.34218/IJEET.11.4.2020.020

(C) IAEME Publication

Scopus Indexed

\title{
ENHANCED POWER GENERATION FROM PLANTS PLANT-E TECHNOLOGY USING HIGH VOLTAGE GAIN DC-DC CONVERTER TOPOLOGY
}

\author{
S. Sarojini Mary \\ Assistant Professor (Sr.gr), Department of Electrical and Electronics Engineering, \\ SRM TRP Engineering College, Tiruchirappalli, Tamilnadu, India.
}

\begin{abstract}
Nowadays world needs renewable and sustainable amount of energy to overcome the demands of electricity. In this paper, the Plant Power concept is based on the living plants in plant microbial fuel cell technology (P-MFC technology) along with bacteria to produce in-situ electricity. Here the plant excretes the organic matter and is broken down by microorganisms in the soil. In this breakdown process, electrons are released. By using this released electron it is possible to harvest them by inserting electrodes and turn them into electricity, without affecting the plant's growth in any way. The aim of the paper is to enhance the renewable electricity by using high voltage gain DC-DC boost converter topology. This configuration includes a single switch, two hybrid voltage multiplier cells and a closed loop three winding coupled inductor. The voltage gain of the converter is enhanced by using its two secondary windings of the coupled inductor, which decreases the stress of power components to deliver a constant dc output voltage.
\end{abstract}

Key words: Sustainable; in-situ; living plants; weak energy source; Waste product; Bacteria; atomic absorption spectroscopy; high boost gain

Cite this Article: S. Sarojini Mary, Enhanced Power Generation from Plants Plant-e Technology Using High Voltage Gain DC-DC Converter Topology. International Journal of Electrical Engineering and Technology, 11(4), 2020, pp. 175-180.

https://iaeme.com/Home/issue/IJEET?Volume=11\&Issue $=4$

\section{INTRODUCTION}

The intimidation of climate variation, the depletion of fossil fuels, ecological greenhouse gasses and the increasing energy demand growth the urgency for new sustainable and reliable energy sources [1]. Several renewable sources such as solar, bio-energy, hydro, and wind technologies are at present implemented in day-to-day life. The plant microbial fuel cell technology (P-MFC technology) is an emergent technology which can harvest electricity via 
living plants. P-MFC technology is renewable and sustainable, because it has a clean conversion and has no opposition for arable land or nature [2].

P-MFC technology is explored at lab-scale, on green roofs [3], other wetlands $[4,5]$ and rice paddy fields [6]. The Plant Power concept is established high-tech and sediment P-MFC systems which improved the output electricity 16 times up to $1.1 \mathrm{~W} / \mathrm{m}^{2}$. The plants transform solar energy into organic matter which is transformed into electricity by electrochemically active bacteria in the fuel cell. The main process which helps plants to function as a source of electricity is Photosynthesis, The electrochemically active bacteria assists the release of electrons i.e., oxidation. We know that "photosynthesis" is a process carried out by plants in which light energy is converted into chemical energy.

The high gain dc-dc boost converters techniques focus on increasing the output power of the P-MFC technology. The high gain dc-dc converter is essential in various applications such as an uninterrupted power supplies (UPS), high intensity discharge (HID) lamp ballast system, the dc- dc converter is necessary to boost the low car battery voltage (12V) to much higher voltage $(100 \mathrm{~V})$. In order to attain high boost conversion ratio with high efficiency, switched-inductor techniques [7], [8] and the switched-capacitor techniques [9], [10] are used. A passive regenerative snubber has been investigated [11] to reduce the serious conduction losses because the voltage stress of the switch in these converters is very high. A single switch high gain converter [12] using a three winding coupled inductor was proposed which extends the voltage conversion ratio and overwhelms the reverse-recovery problem of the output diode, and the leakage energy of coupled It is in these off-grid communities that we believe the technology can make a real difference to people's lives. Thus it is concluded as very useful and blooming technology to promote this natural resource as great one. Although, there is need of huge plant to produce electricity, we can also use road side trees to produce renewable electricity with efficient methodology. The high gain (low input and high output) dc-dc boost converter structure based on diode-capacitor technology and three-winding coupled-inductor used to enhance the voltage of the converter for high step-up and high efficiency conversion, which contains a single switch and two series hybrid voltage multiplier cells.

\section{SYSTEM DESCRIPTION}

The schematic of the Plants Plant-e Technology consisting of a plant microbial fuel cell technology, DC-DC boost converter and the load is shown in Fig. 1. The high gain boost converter is used to enhance the output of the Plant Power.

The first and foremost thing is to have basic knowledge about photosynthesis of plants need carbon dioxide $\left(\mathrm{CO}_{2}\right)$, water $\left(\mathrm{H}_{2} \mathrm{O}\right)$, and sunlight is the process by which plants make their food. Plants make food in their leaves which contain chlorophyll. Chlorophyll is a green chemical that engrosses the sun's energy which colors the leaves. Plants take water from the soil through their xylem goes to the leaves which take $\mathrm{CO}_{2}$ from the air and mixes with the water. "Photosynthesis" can begin all three components (carbon dioxide $\left(\mathrm{CO}_{2}\right)$, water $\left(\mathrm{H}_{2} \mathrm{O}\right)$, and sunlight) are absorbed into the plant's leaves. Then the water molecules are divided into hydrogen $(\mathrm{H})$ and oxygen $\left(\mathrm{O}_{2}\right)$. The $\mathrm{O}_{2}$ is unconfined through the leaves departure the $\mathrm{H}$ and $\mathrm{CO}_{2}$. Energy from the sun turns the combination into a sugar called glucose $\left(\mathrm{C}_{6} \mathrm{H}_{12} \mathrm{O}_{6}\right)$ as shown in (1). 

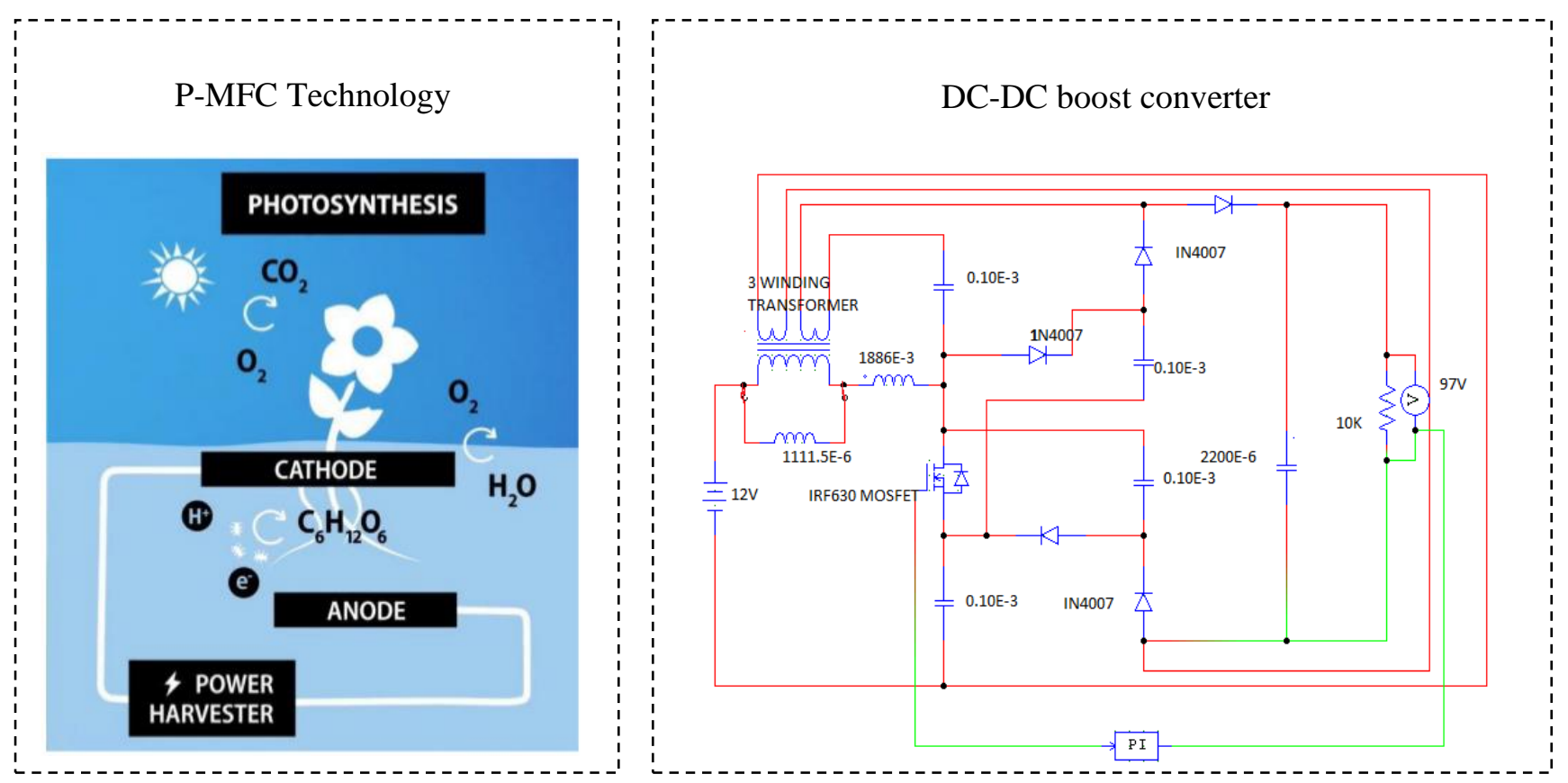

Figure 1 Configuration of the Plants Plant-e Technology considered for study.

The glucose is plant food which gives the plants energy to grow. The organic matter is produced by the "Photosynthesis".

$6 \mathrm{CO}_{2}+12 \mathrm{H}_{2} \mathrm{O}$ Light $\longrightarrow \mathrm{C}_{6} \mathrm{H}_{12} \mathrm{O}_{6}+6 \mathrm{O}_{2}+6 \mathrm{H}_{2} \mathrm{O}$

In the soil, anodic oxidation of organic matter by electrochemically active bacteria is

$\mathrm{C}_{6} \mathrm{H}_{12} \mathrm{O}_{6}+12 \mathrm{H}_{2} \mathrm{O} \rightarrow 6 \mathrm{HCO}_{3}+30 \mathrm{H}+24 \mathrm{E}$

Cathode reduction of oxygen to water is

$6 \mathrm{O}_{2}+24 \mathrm{H}+24 \mathrm{E} \rightarrow 12 \mathrm{H}_{2} \mathrm{O}$

$\mathrm{CO}_{2}$ is fixed by plant leaves using solar energy. Part of the fixed carbon is transported to the roots and released as small molecular weight components. These so called rhizodeposits are partly utilized by electrochemically active bacteria yielding bicarbonate $\left(\mathrm{HCO}_{3}\right)$ as carbon dioxide, protons, and electrons as shown in (2). $\mathrm{CO}_{2}$ is returned to the atmosphere. For gaining metabolic energy shown in equation (3) the electrons are transfer by electrochemically active bacteria to the anode. The anode is coupled to a cathode. The electrons flow from the anode to the cathode shown in Fig.1 through an electrical circuit with a load.

The converter topology is shown in Fig.1, in which a three winding coupled inductor $(T)$ and an ideal transformer with primary winding and two secondary windings [13]. The high voltage gain DC - DC converter [13] uses two parallel passive regenerative snubbers are composed of the diodes and capacitors, through which the energy stored in the leakage inductor can be recycled effectively. Also, converter main switch voltage is clamped to a lower level which helps to improve the efficiency greatly. When the main switch is on, voltage multiplier cells are charged, and the output side capacitor $C_{\mathrm{o}}$ provides energy to the load. When the main switch is off, the primary side and secondary sides of the coupled inductor, input dc source and the two capacitors are connected in series for transferring energy to the load. Therefore, the DC - DC converter can accomplish high-voltage gain in suitable duty cycles and low turns ratios. 
In the proposed DC - DC converter, the turns ratio of the coupled inductor has play a major role on the voltage gain, switch duty cycle, and the voltage stress of power devices. The turns ratio can be

$$
n=\frac{V o}{V i n}(1-D)-\frac{3}{2}
$$

When the converter input voltage and the output voltage are determined by the specific application the duty cycle is chosen less than 0.7 to decrease conduction loss. Then the turns ratio of the coupled inductor can be carried out, the voltage stress of power devices can be calculated easily. Generally, if the duty cycle is too small, the volume of the coupled inductor will be larger due to the bigger turns ratio. As a result, a compromise should be made considering the duty cycle and the turns ratio under given voltage gain. If the leakage inductor of the coupled inductor is not considered, that is to say, $k$ is equal to 1 , the ideal voltage gain is written as:

$$
V o=\frac{2 n+3}{1-D}
$$

By using the experimental results we obtain very high voltage gain.

\section{EXPERIMENTAL RESULTS}

A Plant-e Technology consisting of a Green Aroma plants in series for the required voltage level $(12 \mathrm{~V})$, a DC- DC boost converter and the load is considered to validate the experiments in the laboratory. Green Aroma plants rich with green colour pigments and water content which produce more voltage than other colorful plants. In addition carbon electrode is connected with roots for few hours. In presence of sunlight, the photosynthesis process take place and starts prepare their own food and at the same time they excreting excess amount of photos and electrons to the soil by roots. By using carbon electrode we can easily collect the flow of free electrons in a copper plate. Then the saved output by using rechargeable $12 \mathrm{~V} \mathrm{DC}$ battery.

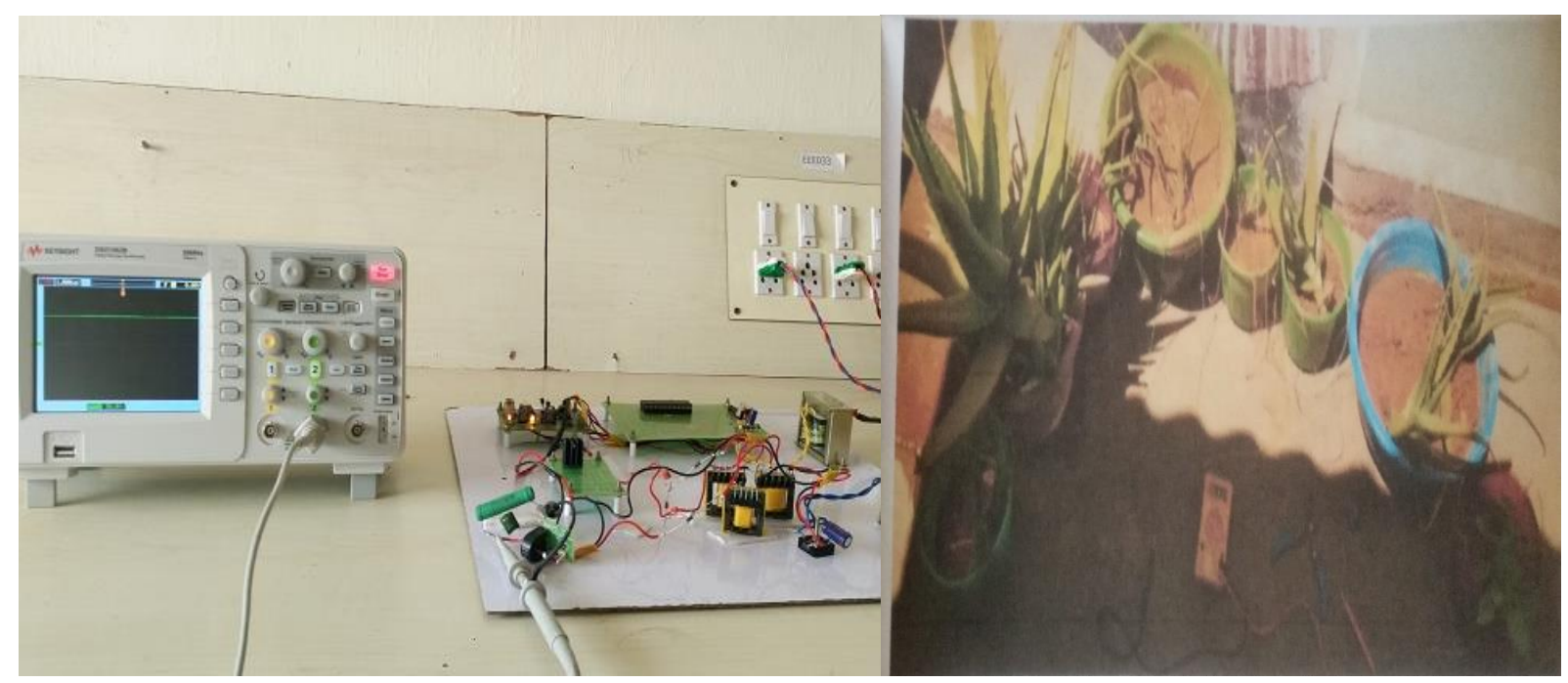

Figure 2 Experimental setup of the proposed Plants Plant-e Technology system. 


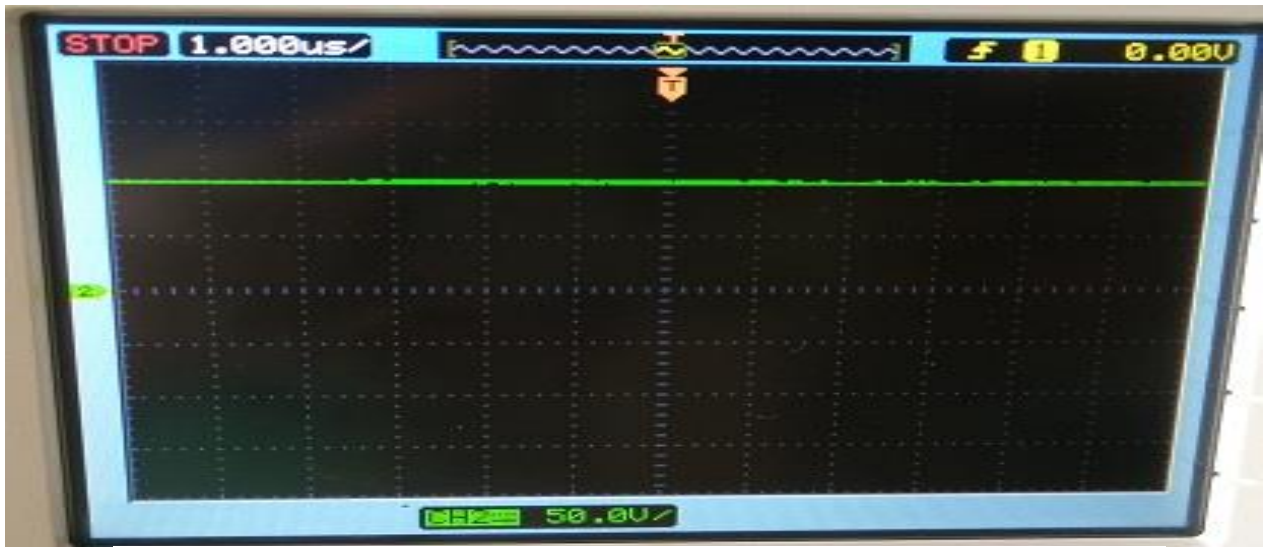

Figure 3 Experimental result for the proposed system

Further the high gain boost DC - DC converter is used to step the voltage gain. The performance of the proposed system has been verified with prototype built in the laboratory is shown in Fig. 2 and the Experimental result for the proposed system is shown in Fig.3. The electric circuit specifications and components are selected as $V_{\text {in }}=12 \mathrm{~V} ; V_{\mathrm{o}}=96 \mathrm{~V} ; N_{1}: N_{2}: N_{3}$ $=1: 1: 1 ; f s=40 \mathrm{KHz} ; \mathrm{C}_{1}=C_{3}=100 \mu F ; C_{2}=C_{4}=220 \mu F$; IRF630 is selected for MOSFET switch and the diodes are $1 \mathrm{~N} 4007$.

\section{CONCLUSION}

This paper addresses P-MFC technology investigated to offer to the clean electricity generation for future researches. P-MFC technology is renewable and sustainable, because it has a clean conversion and possibilities of plant-e to become a successful technology in a market. Few applications like people who affected by cyclone, there is plethora of scarcity towards getting power and water resources. To meet the requirements of renewable as a source using Plants Plant-e Technology as our powerful stepping stone to give the importance to the need of economical purposes. Also, the presented efficient methodology (Plant-e Technology with high voltage gain DC-DC boost converter topology) experimental results can provide the output as 8 times of the input voltage.

\section{REFERENCES}

[1] Hepbasli A. (2008) A key review on exergetic analysis and assessment of renewable energy resources for a sustainable future. Renewable and Sustainable Energy Reviews; 12 (3):593-661.

[2] Strik D.P.B.T.B., Hamelers H.V.M., Snel J.F.H., Buisman C.J.N. (2008) Green electricity production with living plants and bacteria in a fuel cell. International Journal of Energy Research. 32(9):870-876.

[3] Helder M., Chen W.S., Van der Harst E.J.M., Strik D.P.B.T.B., (2013) Hamelers H.V.M.,Buisman C.J.N., Potting J. Electricity production with living plants on a green roof: Environmental performance of the plant-microbial fuel cell. Biofuels, Bioproducts and Biorefining. 7(1):52-64.

[4] Wetser K., Liu J., Buisman C.J.N., Strik D.P.B.T.B. (2015) Plant microbial fuel cell applied in wetlands: Spatial, temporal and potential electricity generation of Spartina anglica salt marshes and Phragmites australis peat soils. Biomass and Bioenerg; 83:543550 . 


\section{DC-DC Converter Topology}

[5] Dai J., Wang J.J., Chow A.T., Conner W.H. (2014) Electrical energy production from forest detritus in a forested wetland using microbial fuel cells. GCB Bioenerg; 7(2):244252.

[6] Kaku N., Yonezawa N., Kodama Y., Watanabe K. (2008) Plant/microbe cooperation for electricity generation in a rice paddy field. Applied Microbiology an Biotechnology; 79(1):43-49.

[7] Y. Tang, D. J. Fu, T. Wang, and Z. W. Xu, (2015) "Hybird switched-inductor converters for high step-up conversion," IEEE Trans. Ind. Electron., vol. 62, no. 3.

[8] Y. H. Chang, and Y. J. Chen, (2014) "Modeling and implementation ofhigh-gain switched-inductor switched-capacitor converter," in proc. IEEE ISIC Conf., pp. 9-12.

[9] O. Abutbul, A. Gherlitz, Y. Berkovich, and A. Ioinovici, (2009) "Step-upswitching-mode converter with high voltage gain using a switched-capacitor circuit," converter with high step-up voltage gain," IEEE Trans. Ind. Electron,vol.56, no.8, pp. 3144-3152.

[10] B. Axelrid, Y. Berkovich, and A. Ioinovici, (2008) "Switched capacitor /switchedinductor structures for getting transformerless hybrid DC-DC PWM converters," IEEE Trans. Circuits Syst.I, vol. 55, no.2, pp. 687-696.

[11] R. J. Wai, and R. Y. Duan, (2005) "High step-up converter with coupled-inductor," IEEE Trans. Power Electron., vol. 20, no. 5, pp. 1025-1035.

[12] Mohammad Khalilzadeh, Karim Abbaszadeh, (2015) "Non-isolated high step-up DC-DC converter based on coupled inductor with reduced voltage stress," IET Power Electronics. Vol. 8, Iss. 11, pp. 2184-2194.

[13] xuefeng hu, jianzhang Wang, Linpeng Li, Yongchao Li. (2017) "A Three-Winding CoupledInductor DC-DC Converter Topology with High Voltage Gain and Reduced Switch Stress" EEE Transactions on Power Electronics.

[14] Dr. Y. L. ChandraShekar and Dr. P.S. Puttaswamy, (2017) Design and Simulation of Improved Dc-Dc Converters Using Simulink for Grid Connected PV Systems. International Journal of Electronics and Communication Engineering and Technology, 8(6), pp. 62-71.

[15] Nisha S.Singh, C.S.Khandelwal, (2014) DSPIC Based Digitized Feedback Loop for DCDC Converter, International Journal of Electronics and Communication Engineering \& Technology, 5(5), pp. 105-110. 